УДК 657.24

\title{
ОРГАНІЗАЦІЯ БЕЗПАПЕРОВОГО УПРАВЛІНСЬКОГО ОБЛІКУ НА ПІДПРИЄМСТВАХ МАЛОГО БІЗНЕСУ
} ORGANIZATION OF PAPERLESS MANAGEMENT
ACCOUNTING IN SMALL BUSINESS ENTERPRISES

\author{
Гаркуша Сергій Анатолійович \\ кандидат економічних наук, доцент, \\ Сумський національний аграрний університет \\ ORCID: https://orcid.org/0000-0002-2043-1217
}

Harkusha Serhii

Sumy National Agrarian University

\begin{abstract}
Стаття присвячена дослідженню організації безпаперового управлінського обліку на малих підприємствах. На сьогоднішній день значні зміни умов господарювання, що відбуваються в економіці країни, вимагають підвищення якості інформації, яку використовують для прийняття управлінських рішень. Досліджено основні переваги та недоліки основних систем управлінського обліку та показані найбільш типові проблеми, що виникають у сучасних умовах при впровадженні управлінського обліку на малих підприємствах України. Порівняно особливості систем обліку за МСФЗ і НП(С)БО для використання в управлінському обліку. Розглянуто програмне забезпечення для ведення управлінського обліку малими підприємствами. Що стосується обмежень дослідження, слід визнати, що дослідження було зосереджено виключно на впроваджені управлінського обліку на малих підприємствах.
\end{abstract}

Ключові слова: управлінський облік, мале підприємство, автоматизація обліку, безпаперовий облік.

Статья посвящена исследованию организации безбумажного управленческого учета на малых предприятиях. На сегодняшний день значительные изменения условий хозяйствования, происходящие в экономике страны, требуют повышения качества инорормации, используемой для принятия управленческих решений. Исследованы основные преимущества и недостатки основных систем управленческого учета и показаны наиболее типичные проблемы, возникающие в современных условиях при внедрении управленческого учета на малых предприятиях Украины. Проведено сравнение особенностей систем учета по МСФО и НП(С)БУ для использования в управленческом учете. Рассмотрены программное обеспечение для ведения управленческого учета малыми предприятиями. Что касается ограничений исследования, следует признать, что исследование было сосредоточено исключительно на внедрены управленческого учета на малых предприятиях.

Ключевые слова: управленческий учет, малое предприятие, автоматизация учета, безбумажный учет.

The article considers the organization of paperless management accounting in small enterprises. It is determined that management accounting is the basis of a paperless information system, which allows you to make informed management decisions, both in the short and long term. It is established that it is expedient for small business to introduce paperless management accounting, as: small business is strongly influenced by external changes; management accounting needs to be adjusted so that it is as clear as possible; with the established account it is possible to analyze consequences of decisions; accounting helps manage cash flows. A comparison of the features of IFRS and NAR (S) accounting systems for use in management accounting was performed. It is concluded that the financial data of IFRS are more suitable for management purposes, as initially these standards were created taking into account the needs of investors to make economic decisions, the principles and objectives of IFRS largely correspond to the principles and objectives of management accounting. The tasks of the implemented system of management accounting at the small enterprise which consist in the control of economic efficiency of work of the enterprise and the centers of responsibility are defined; improving the system of operational management of the enterprise; ensuring effective control over the availability, rational distribution, movement of property, labor, financial and material resources for the rapid achievement of goals by the enterprise, etc. The software for paperless management accounting is given and their characteristic is given. It is established that any program will have both positive and negative components, as developers will never be able to take into account all the variety of factors and 
the rate of change in market conditions in today's world. It is concluded that when organizing a system of paperless management accounting in small businesses, errors often occur: managers of small businesses seek to automate all processes; insufficient funding; lack of clear tasks. The introduction of a paperless management accounting system allows the company's management to make the right decisions based on data on the economic condition of the enterprise.

Keywords: management accounting, small business, accounting automation, without paper accounting.

Постановка проблеми. Немає нічого більш небезпечного для бізнесу, як прийняття важливих рішень наосліп. Якщо власник або керівник бізнесу, то безумовно $€$ потреба адекватної інорормації для прийняття як стратегічних, так і тактичних управлінських рішень. Коли бізнес включає в себе лише кілька господарських операцій, тримати в голові всю інфрормацію не так складно. Функцію управлінського обліку виконують пам'ять власника, записи в зошиті, позначки в щоденнику. Але 3 ростом бізнесу кількість господарських операцій зростає в геометричній прогресії, і запам'ятати все вже нереально. Важливо не упустити момент, в який необхідно змінити ставлення до контролю над процесами на підприємстві. В іншому випадку ефрективність роботи почне різко знижуватися: власник впевнений в тому, що володіє повною інфрормацією про свій бізнес, а в реальності справи йдуть зовсім по-іншому.

Управлінський облік дає змогу побачити, які джерела доходу перспективні, які напрямки розвитку можуть принести прибуток, а що приносить тільки збитки. Без нього неможливо управляти малим підприємством, розуміти, до чого прагнути і досягати бажаного.

Аналіз останніх досліджень і публікацій. Значний внесок у розвиток теоретичних, методичних, методологічних та прикладних аспектів організації управлінського обліку на підприємствах малого бізнесу зробили Ніпорко Н.І., Гоголь Т.А., Маргасова В.Г., Рибальченко Д. та ін.

Проблем теорії та методології управлінського обліку приділяється достатня увага в роботахзарубіжнихіукраїнськихвчених. Однак більшість вітчизняних розробок щодо вдоліку, на практиці України слабо впроваджуються, що пов'язано з відсутністю економічної культури і кваліфрікації власника підприємства, керівного персоналу і облікових кадрів. Незважаючи на об'єктивну потребу, управлінський облік до сих пір не отримав належного застосування на малих підприємствах України. Це пов'язано, очевидно, з розбіжністю поглядів на розуміння сенсу даного питання. Так, одні фрахівці вважають управлінський облік як підсистему бухгалтерського обліку, а інші як систему управління підприємством. У той же час більшість фрахівців сходяться на думці, що головною метою управлінського обліку $є$ орормування інсрормації, необхідної для прийняття рішень на різних рівнях управління. На наш погляд, до цієї проблеми необхідно підходити комплексно. Досвід діяльності зарубіжних підприємств дає переконливі аргументи на користь того, що управлінський облік слугує основою безпаперової інформаційної системи, яка дозволяє обґрунтовано приймати управлінські рішення, як на короткострокову, так і на тривалу перспективу.

Історично склалося, що більшість малих підприємств ведуть бухгалтерський облік лише для формування показників фрінансової та податкової звітності. Тобто підприємці не приділяють належної уваги власне обліку як джерелу інфрормації для себе, а розглядають його як просту повинність, зайву трату часу і фрінансових ресурсів [1, с. 379].

Запорукою успіху підприємства $€$ правильно обрана стратегія і ефективна система внутрішнього контролю. Розуміння стратегії починається 3 визначення цілі і довгострокових напрямків діяльності підприємства. Проте на малому підприємстві, яке постійно має пристосовуватися до мінливих умов зовнішнього середовища, має існувати спрощений підхід до формування стратегії розвитку та системи внутрішнього управлінського контролю [2, с. 405].

Зазвичай в Україні управлінський облік може виглядати наступним чином:

- вручну на паперових носіях;

- у таблицях Excel. Близько 80\% компаній - представників малого та середнього бізнесу - віддають перевагу саме цьому варіанту. Це просто і дешево. Але при цьому в Excel неможливо розділити рівні доступу до інсрормації, повністю автоматизувати управлінську звітність з первинних документів і найсумніше - дані можуть губитися;

- автоматизовано у спеціальних програмах.

Виділення невирішених раніше частин загальної проблеми. Однак питання організації безпаперового управлінського обліку на малих підприємствах з урахуванням спе- 
циоріки їх діяльності потребують додаткового вивчення і дослідження.

Формулювання цілей статті (постановка завдання). Метою статті $€$ дослідження теоретичних засад фрормування системи безпаперового управлінського обліку на малих підприємствах.

У процесі проведення наукових досліджень методологічною основою стали концептуальні основи та стандарти обліку і звітності, діалектичний метод пізнання. Для вивчення стану та проблем впровадження управлінського обліку на практиці підприємств використано аналітичний, порівняльний методи дослідження, а також абстрактно-логічні підходи до пошуку та обґрунтування шляхів подолання окреслених проблем.

Виклад основного матеріалу дослідження. Для есрективності бізнесу зараз, як ніколи, потрібна розвинена IT-інорраструктура, яка забезпечить оперативну і функціональну діяльність підприємства будь-якого профрілю. Однією з важливих завдань ІТ-системи є взаємодія та обмін даними між різними програмними продуктами. Така інтеграція економить час і ресурси, підвищує якість та есрективність роботи підприємства.

Управлінський облік, на відміну від бухгалтерського обліку, дає можливість вести облік прибутку не тільки по підприємству в цілому, але і за окремими напрямками діяльності, проектами та підрозділами. 3 підсумкового фрінансового звіту, сорормованого в управлінському програмному забезпеченні, керівництво отримає достовірну і оперативну інфрормацію про результати діяльності всього підприємства, напрямків діяльності та підрозділів.

Практично вести облік прибутку окремих ділянок бізнесу й дізнатися рентабельність кожного з них досить важко. Значно полегшує завдання програма безпаперового управлінського обліку, в якій всі доходи та витрати фріксуються з аналітикою за видами бізнесу, проектами або підрозділами.

Для більшості облікових систем актуальні три методи збору і обробки даних:

- інформація бухгалтерського обліку потрапляє в бази даних окремо від інформації управлінського обліку. Даний варіант відрізняє висока трудомісткість.

- дані, отримані в обліку, перетворюються для подальшого використання в управлінському обліку. Однак повна автоматизація процесу переносу даних неможлива в зв'язку з необхідністю в доповненні бухгалтерської інорормації.
- дані, отримані в управлінському обліку, перетворюються для подальшого використання в бухгалтерському. Відбувається автоматичне вивантаження ключових операцій 3 бази управлінського обліку в базу бухгалтерського обліку. У той же час, операції, що відрізняються за змістом, ведуться окремо.

Практика показує, що найбільшою популярністю користується перший варіант. Причиною тому $\epsilon$ небажання бухгалтерів бути відповідальними за управлінський облік. В ході розвитку підприємства поступово переходять до автоматизації перенесення даних між бухгалтерським і управлінським обліком. Це дозволяє зробити бізнес більш прозорим.

Впровадження управлінського обліку на підприємстві - одне 3 найбільш ефективних рішень, яке позбавляє багатьох проблем. Тому його давно з успіхом стали застосовувати країни Євросоюзу, а тепер активно використовують і в Україні.

Малому бізнесу також доцільно запровадити безпаперовий управлінський облік, оскільки: на малий бізнес дуже впливають зовнішні зміни; управлінський облік потрібно налаштувати під себе, щоб він був максимально зрозумілий; з налагодженим обліком можна аналізувати наслідки рішень; облік допомагає управляти грошовими потоками.

Більшість малих підприємств десятками років працюють і не замислюються про необхідність впровадження управлінського обліку. На самих ранніх етапах запровадження або удосконалення системи безпаперового управлінського обліку на підприємстві необхідно визначити, яку фрінансову інсрормацію необхідно інтегрувати в цю систему. Найчастіше вибір стоїть між фрінансовою інфрормацією, що формується на основі національних стандартів бухгалтерського обліку (НП(С)БО), МСФЗ або фрінансовою інформацією відповідно до внутрішніх регламентів підприємства. Відмінності між системами обліку визначаються, головним чином, метою формування такої інфрормації і потребами користувачів. У таблиці 1 дано порівняння різних систем обліку щодо застосовності для цілей управлінського обліку.

Фінансова інформація на основі НП(С)БО формується в основному для надання контролюючим органам, правила досить жорстко регламентовані, методологія бухгалтерського обліку часто зближені з податковим обліком, процедури обліку відрізняються формальним підходом. Переваги даної системи в тому, що стандарти національної 
Порівняння особливостей систем обліку МСФЗ і НП(С)БО

Таблиця 1 для використання в управлінському обліку

\begin{tabular}{|c|c|c|c|}
\hline Параметр & НП(С)БО & МСФ3 & Управлінський облік \\
\hline Мета & $\begin{array}{l}\text { Подання звітності } \\
\text { контролюючим } \\
\text { органам у відпо- } \\
\text { відності до законо- } \\
\text { давства України }\end{array}$ & $\begin{array}{l}\text { Прийняття } \\
\text { економічних рішень, } \\
\text { представлення } \\
\text { звітності контро- } \\
\text { люючим органам }\end{array}$ & $\begin{array}{l}\text { Формування інорормації для } \\
\text { стратегічного і оперативного } \\
\text { управління підприємством, } \\
\text { прийняття економічних } \\
\text { рішень, підвищення } \\
\text { ефрективності управління }\end{array}$ \\
\hline Методологія & $\begin{array}{l}\text { Законодавство } \\
\text { України, можуть } \\
\text { застосовуватися } \\
\text { МСФЗ }\end{array}$ & $\begin{array}{l}\text { МСФ3; широке } \\
\text { застосування про- } \\
\text { фесійних суджень }\end{array}$ & $\begin{array}{l}\text { Внутрішня методологія, яка } \\
\text { розроблена підприємством; } \\
\text { можуть застосовуватись } \\
\text { загальновідомі інструменти } \\
\text { та моделі }\end{array}$ \\
\hline $\begin{array}{l}\text { Вимоги } \\
\text { законодавства } \\
\text { України }\end{array}$ & $\begin{array}{l}\text { Вимоги і регламенти } \\
\text { застосовуються до } \\
\text { обліку та фрінансової } \\
\text { звітності і консолідо- } \\
\text { ваної фрінансової } \\
\text { звітності юридичних } \\
\text { осіб усіх фрорм влас- } \\
\text { ності (крім банків та } \\
\text { бюджетних установ) }\end{array}$ & $\begin{array}{l}\text { Вимоги і регламенти } \\
\text { законодавства } \\
\text { України обмежені }\end{array}$ & $\begin{array}{l}\text { Вимоги і регламенти } \\
\text { законодавства України } \\
\text { не застосовуються }\end{array}$ \\
\hline $\begin{array}{l}\text { Контроль форо- } \\
\text { мування і подан- } \\
\text { ня звітності }\end{array}$ & $\begin{array}{l}\text { Державні контролюючі } \\
\text { органи }\end{array}$ & $\begin{array}{l}\text { Інвестори, керів- } \\
\text { ництво, контролюючі } \\
\text { органи }\end{array}$ & Керівництво \\
\hline $\begin{array}{l}\text { Відповідальність } \\
\text { за фрормування } \\
\text { звітності }\end{array}$ & $\begin{array}{l}\text { Вище керівництво } \\
\text { і виконавці }\end{array}$ & Менеджмент & $\begin{array}{l}\text { Менеджмент різного рівня, в } \\
\text { межах зони відповідальності }\end{array}$ \\
\hline Користувачі & Зовнішні і внутрішні & Зовнішні і внутрішні & Внутрішні \\
\hline
\end{tabular}

звітності звичні і зрозумілі більшості українських срахівців, кожне підприємство фрормує звітність відповідно до законодавства в обов'язковому порядку, тому такі фрінансові дані вже готові до використання в управлінській обліковій системі, отже, додаткові витрати можуть бути мінімальними. Однак, внаслідок відмінності завдань управлінської звітності та звітності НП(С)БО, фрінансових даних НП(С)БО може виявитися недостатньо, а також така інфрормація часто не відповідає потребам управління.

Аналізуючи мету і потреби користувачів, на яких орієнтована звітність, можна зробити висновок, що з метою управління більше підходять фрінансові дані МСФЗ, так як спочатку ці стандарти створювалися 3 урахуванням потреб інвесторів для прийняття ними економічних рішень. Принципи та завдання МСФЗ багато в чому відповідають принципам та завданням управлінського обліку. Вимоги МСФЗ до процедури обліку і фрормату звітності гнучкіші, ніж вимоги НП(С)БО. У звітності МСФЗ менеджмент прагне продемонструвати позитивну динаміку активів, прибутку та інших показників. Широко застосовуються професійні судження, оцінка активів і зобов'язань заснована на категоріях майбутнього. Витрати на фрормування звітності МСФЗ можуть бути досить істотними для невеликих підприємств, проте якість такої інфрормації для управлінської звітності досить висока.

Завдання впровадженої системи управлінського обліку на малому підприємстві, на наш погляд, заключаються в наступному:

- контроль економічної ефективності роботи підприємства і центрів відповідальності;

- удосконалення системи оперативного управління підприємством;

- забезпечення ефрективного контролю над наявністю, раціональним розподілом, рухом майна, трудових, фрінансових і матеріальних ресурсів для швидкого досягнення поставлених цілей підприємством;

- виявлення резервів поліпшення есрективності роботи;

- скорочення витрат підприємства;

- форомування показників, які сприяють прийняттю максимально ефрективних управлінських рішень; 
- використання сучасних методик калькуляції собівартості одержуваної продукції для ціноутворення, прийняття розумних управлінських рішень стосуються асортименту продукції та інших цілей;

- забезпечення стійкої позиції підприємства на ринку;

- мінімізація кредиторської та дебіторської заборгованості;

- перерозподіл оборотних коштів організації 3 метою отримання максимального прибутку;

- розробка рекомендацій спрямованих на поліпшення фрінансового становища підприємства;

- фрормування міцної інфрормаційної бази для управління підприємством;

- отримання загальної концепції фрункціонування управлінського обліку;

- впровадження і застосування в підприємстві складових системи управлінського обліку 3 метою вирішення поставлених завдань замовником;

- управління поточною ліквідністю підприємства.

У процесі запровадження управлінського обліку необхідно правильно вибрати програмний продукт.

У таблиці 2 наведено деякі найпоширеніші програмні рішення на ринку облікових інсрормаційних технологій України.

Автоматична система має кілька важливих переваг: швидке виявлення будь-яких проблем і невідповідностей; прискорення пошуку потрібної інорормації; збільшення достовірності даних; спрощення підготовки інсрормації і складання звітів.

Автоматизація - це тривалий процес, який може займати близько року. Після цього кілька років буде потрібно на доопрацювання системи. При цьому на початковому етапі зростає навантаження на відповідальних співробітників.

Дуже відповідальний крок - це вибір програмного забезпечення, в якому буде вестися управлінський облік. Звичайно, можливості у всіх підприємств різні, але на наш погляд для цього потрібна лише одна програма, в якій буде можливо здійснювати і операційну діяльність і паралельно автоматично фрормувати управлінський облік. Це в підсумку дасть велику економію, ніж покупка окремих модулів, програм, в які будуть перекачувати первинну інорормацію, і вносити аналітику управлінського обліку.

В кінцевому рахунку, будь-яка програма буде мати як позитивні, так і негативні скла- дові, оскільки розробники ніколи не зможуть врахувати всього різноманіття фракторів і швидкості зміни ринкової кон'юнктури в сьогоднішньому світі. Для того щоб вибрати найбільш підходящий продукт для малого підприємства необхідно розглядати пропоновані рішення в контексті предметного застосування вбудованих можливостей і потреб управлінського обліку. Тільки при дотриманні цієї умови є велика ймовірність вибору оптимального програмного рішення і отримання від його використання максимальної користі.

Багато фрахівців в своїй повсякденній діяльності використовують або використовували Excel. Здається на перший погляд, що Excel $\epsilon$ ідеальною системою. Хоча Excel не $\epsilon$ базою даних, проте він $\epsilon$ досить потужною платорормою, яка при правильному підході без збоїв дозволяє обробляти великі обсяги даних.

Складнощі, що виникають при використанні Excel, змушують користувачів займатися одноманітною і нудною роботою, більшу частину часу пов'язаної з трудомісткими ручними процедурами. По суті, система управлінського обліку на платорормі Excel - це набори непов'язаних фрайлів, між якими дані переносяться практично вручну копіюванням і вставкою.

3 огляду на всі складнощі використання Excel в управлінському обліку, підприємствам 3 подібною технологією доцільно використовувати програмні продукти 3 автоматизації управлінського обліку. Перехід на ці системи звільнить користувачів від трудомісткої роботи ручного ведення таблиць і фрайлів, скоротить час обробки вхідної інсрормації та отримання звітних фрорм управлінського обліку.

Висновки. При організації системи безпаперового управлінського обліку на малих підприємствах часто виникають помилки:

- керівники невеликих підприємств прагнуть автоматизувати всі процеси. В результаті вони витрачають величезні суми на цей процес, але для малого бізнесу автоматизація не принесе великої вигоди, а лише створить додаткові труднощі;

- недостатнє фрінансування. При впровадженні системи управлінського обліку можна економити на розробці проекту і навчанні людей. Витрати незабаром окупляться і принесуть підприємству велику вигоду;

- відсутність чітких завдань. Щоб системи управлінського обліку приносила великий 
Програмне забезпечення для безпаперового управлінського обліку та їх характеристика на підприємствах України

\begin{tabular}{|c|c|c|}
\hline \multirow{2}{*}{$\begin{array}{c}\text { Програмне } \\
\text { забезпечення }\end{array}$} & \multicolumn{2}{|c|}{ Характеристика } \\
\hline & Призначення та переваги & Недоліки при тестуванні \\
\hline Microsoft Excel & \begin{tabular}{|l} 
Найбільш поширений метод ведення \\
обліку в малому бізнесі. Вибір даного \\
методу обумовлений, з одного боку, мож- \\
ливістю застосовувати досить великий \\
набір вбудованих інструментів і до пев- \\
ної міри автоматизувати облік за рахунок \\
взаємозв'язку таблиць і величезної кіль- \\
кості складних рукописних формул, а з \\
іншого - підкріплюється дещо умовною \\
«безкоштовністю» даного методу
\end{tabular} & $\begin{array}{l}\text { На наш погляд, його не можна на } \\
100 \% \text { назвати автоматизованим } \\
\text { методом, швидше за напівавто- } \\
\text { матичним, } 3 \text { деякими автомати- } \\
\text { зованими ділянками. Цей метод } \\
\text { передбачає велику ймовірність } \\
\text { помилок, вартість яких може вимі- } \\
\text { рюватися десятками і сотнями } \\
\text { тисяч упущених вигод для підпри- } \\
\text { ємства через складність в реаль- } \\
\text { ному налаштуванні взаємозв'язку } \\
\text { безлічі таблиць і відсутності меха- } \\
\text { нізму захисту від недостовірних } \\
\text { даних. } \\
\text { Облік побудований таким чином } 3 \\
\text { натяжкою можна назвати безпеч- } \\
\text { ним з точки зору зберігання даних }\end{array}$ \\
\hline $\begin{array}{l}\text { BAS } \\
\text { Комплексне } \\
\text { управління } \\
\text { підприємством }\end{array}$ & $\begin{array}{l}\text { є комплексним рішенням, що охоплює } \\
\text { основні контури управління та обліку. } \\
\text { Рішення дозволяє організувати єдину } \\
\text { інфородмацйу систему для управління } \\
\text { різними аспектами діяльності підпри- } \\
\text { ємств малого і середнього бізнесу. «ВАS } \\
\text { Комплексне управління підприємством» } \\
\text { дозволяє збільшити продуктивність праці } \\
\text { всіх служб підприємства та покращити } \\
\text { процеси взаємодії підрозділів [4] }\end{array}$ & $\begin{array}{l}\text { Для роботи програми необ- } \\
\text { хідно аби операційна система } \\
\text { комп'ютера відповідала вимогам } \\
\text { розробника. Навіть порожня база } \\
\text { займає близько } 300 \text { МВ пам'яті } \\
\end{array}$ \\
\hline $\begin{array}{l}\text { BAS } \\
\text { Управління } \\
\text { торгівлею }\end{array}$ & $\begin{array}{l}\text { є інструментом для підвищення ефектив- } \\
\text { ності бізнесу торговельного підприємства. } \\
\text { Рішення дозволяє збільшити продуктив- } \\
\text { ність праці багатьох служб підприємства, } \\
\text { працювати з оперативною інфрормацією, } \\
\text { яка відображає поточний стан операцій- } \\
\text { ної діяльності, швидко і в зручній фрормі } \\
\text { отримувати звіти для прийняття рішень } \\
\text { на різних рівнях [5] }\end{array}$ & $\begin{array}{l}\text { Потрібно купувати кілька інших } \\
\text { продуктів ВАS для розгортання. } \\
\text { Через кількість модулів складно } \\
\text { налаштовувати. Призначена в } \\
\text { більшій мірі для обліку товарних } \\
\text { запасів } \\
\end{array}$ \\
\hline $\begin{array}{l}\text { BAS Малий } \\
\text { бізнес }\end{array}$ & $\begin{array}{l}\text { Дає можливість фрормувати управлін- } \\
\text { ський план рахунків та проводок доку- } \\
\text { ментів, які дозволяють вести управлін- } \\
\text { ський облік: формування управлінського } \\
\text { балансу та аналіз фрінансових показників } \\
\text { діяльності компанії. Містить спеціальний } \\
\text { розділ для керівника «Монітор керів- } \\
\text { ника», який дозволяє керувати діяль- } \\
\text { ністю підприємства та контролювати по } \\
\text { основних показниках }\end{array}$ & $\begin{array}{l}\text { Для роботи програми необхід- } \\
\text { но аби операційна система ком- } \\
\text { п'ютера відповідала вимогам роз- } \\
\text { робника. Навіть порожня база } \\
\text { займає близько } 200 \text { МВ пам'яті }\end{array}$ \\
\hline
\end{tabular}

прибуток необхідно точно сформулювати цілі підприємства, визначити терміни для їх досягнення і розробити проект відповідно до них.

Але, впровадження системи безпаперового управлінського обліку дозволяє керівництву підприємства безпомилково приймати правильні рішення на основі даних про економічний стан підприємства. Що стосується обмежень дослідження, слід визнати, що дослідження було зосереджено виключно на впроваджені управлінського обліку на малих підприємствах. 


\section{СПИСОК ВИКОРИСТАНИХ ДЖЕРЕЛ:}

1. Ніпорко Н.І. Формування системи обліку на малому підприємстві: управлінський аспект. Проблеми і перспективи економіки та управління. 2015. № 4. С. 377-384. URL: http://nbuv.gov.ua/UJRN/ppeu_2015_4_54.

2. Гоголь Т.А., Маргасова В.Г. Організація управлінського обліку і контролю на підприємствах малого бізнесу. Вісник ХНАУ ім. В.В. Докучаєва. 2018. № 2. С. 401-411. URL: http://dspace.knau.kharkov.ua/jspui/ bitstream/123456789/1733/1/Гоголь\%20Т.А.\%2с\%20Маргасова\%20В.Г.pdf.

3. Рибальченко Д. Управлінська звітність: кому, коли, навіщо. Погляди. 2020. 11 березня. URL: https://thepage.ua/ ua/experts/upravlinska-zvitnist-komu-koli-navisho.

4. BAS Комплексне управління підприємством. Офріційний сайт програмного продукту BAS. URL: https://www.bas-soft.eu/soft/bas-mass/bas-integrated-enterprise-management.

5. BAS Управління торгівлею. Офріційний сайт програмного продукту BAS. URL: https://www.bas-soft.eu/ soft/bas-mass/bas-trade-management.

\section{REFERENCES:}

1. Niporko N.I. (2015) Formuvannia systemy obliku na malomu pidpryiemstvi: upravlinskyi aspect [The formation of the accounting system on a small enterprise: managerial aspect]. Problemy i perspektyvy ekonomiky ta upravlinniaProblems and prospects of economics and management, no. 4, pp. 377-384. Available at: http://nbuv.gov.ua/UJRN/ ppeu_2015_4_54. (in Ukrainian)

2. Hohol T.A., Marhasova V.H. (2018) Orhanizatsiia upravlinskoho obliku i kontroliu na pidpryiemstvakh maloho biznesu [Organization of management accounting and control in small businesses]. Visnyk KhNAU im. V.V. Dokuchaieva - Bulletin of KhNAU named after V.V. Dokuchaeva, no. 2, pp. 401-411. Available at: http://dspace.knau.kharkov.ua/jspui/bitstream/123456789/1733/1/Гоголь\%20т.А.\%2c\%20Маргасова\%20В.Г.pdf (in Ukrainian)

3. Rybalchenko D. (2020). Upravlinska zvitnist: komu, koly, navishcho [Management reporting: to whom, when, why]. Pohliady - Views, March 11th. Available at: https://thepage.ua/ua/experts/upravlinska-zvitnist-komu-kolinavisho. (in Ukrainian)

4. BAS Kompleksne upravlinnia pidpryiemstvom [BAS Integrated enterprise management]. Official site of the BAS software product. Available at: https://www.bas-soft.eu/soft/bas-mass/bas-integrated-enterprise-management. (in Ukrainian)

5. BAS Upravlinnia torhivleiu [BAS Trade Management]. Official site of the BAS software product. Available at:https://www.bas-soft.eu/soft/bas-mass/bas-trade-management. (in Ukrainian) 